Copyright (C) 2021 by Cherkas Global University

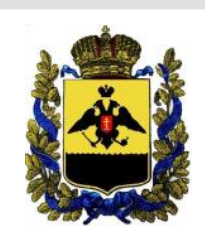

Published in the USA

Bylye Gody

Has been issued since 2006.

E-ISSN: 2310-0028

2021. 16(4): 1814-1825

DOI: $10.13187 /$ bg.2021.4.1814

Journal homepage:

https://bg.cherkasgu.press

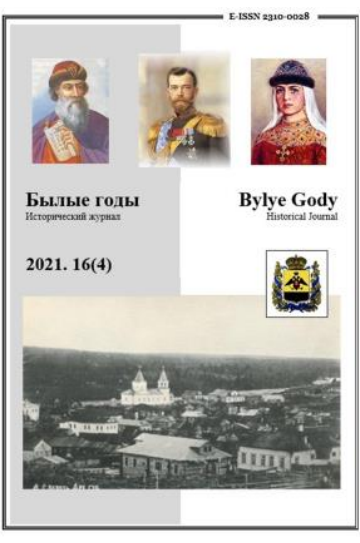

\title{
Formation of a System of Excise Taxes in the Central Asian Outskirts of the Russian Empire (second half of the 19th - early 2oth centuries)
}

\author{
Yuliya A. Lysenko a, b, c,* \\ a Altai State University, Barnaul, Russian Federation \\ b Cherkas Global University, Washington, USA \\ c Volgograd State University, Volgograd, Russian Federation
}

\begin{abstract}
The article analyzes the process of creating a system of excise taxes in the Central Asian outskirts of the Russian Empire on the basis of historical sources of diverse origins, which were introduced into scientific circulation at first. It is noted that the goal of the excise reform in the Steppe Territory and Turkestan was to modernize and integrate this ethnoregion into the Russian economy, to increase its profitability. In the Steppe Territory, an increase in excise receipts to the state treasury in the second half of the 19th century was associated with the development, first of all, of the distillery industry. A number of factors contributed to this situation: permission for the free production of alcohol, unlimited trade in alcoholic beverages, the development of the raw material base of this industry and an increase in demand for products due to a sharp influx of the peasant population into the region. After the introduction the state wine monopoly, the size of excise taxes in the regions of the Steppe region began to decline at the beginning of the twentieth century. In Turkestan, the introduction of the provisions of the excise reform began later - in the 70-80s of the XIX century. This was due to the later involvement of the region in the modernization processes, the lack of demand for wine and vodka products, the orientation of government circles to the development of cotton farms. Nevertheless, by the end of the 19th century, as a result of the development of the railway network, the distillery industry in Turkestan, oriented towards the Russian market, began to bring significant tax revenues. State wine monopoly did not affect the region at the beginning of the twentieth century.
\end{abstract} Turkestan.

Keywords: excise reform, distillery industry, state wine monopoly, Russian Empire, Steppe region,

\section{1. Введение}

Как известно, одним из направлений модернизации, осуществлявшейся в Российской империи в 1860-1870-х гг., являлась налоговая система. Перед Министерством финансов ставилась задача повышения рентабельности региональных экономик, в том числе за счет роста численности прямых и косвенных налогов. Это в свою очередь требовало пересмотра государственной налоговой политики, ее подходов и принципов. В русле решения данных задач была проведена так называемая «акцизная реформа», законодательно оформленная Положением о питейном сборе от 4 июля 1861 г. (Положение о питейном сборе..., 1862).

Положение 1861 г. кардинально трансформировало существовавший в стране механизм поступления налогов в государственную казну от производства и продажи спиртных напитков. Как отмечает Л.В. Артемьева, «взамен исключительного права государства на производство и торговлю спиртными напитками, сдаваемого на откуп, предполагалось разрешить свободное производство спирта и ничем не ограниченную торговлю алкогольной продукцией» (Артемьева, 2011: 57).

\footnotetext{
${ }^{*}$ Corresponding author

E-mail addresses: iulia_199674@mail.ru (Yu.A. Lysenko)
} 
Правительство рассчитывало создать здоровую конкурентную среду на рынке алкогольной продукции и таким образом повысить доходность данной отрасли, обеспечив неизменный рост налоговых поступлений в государственную казну. Налоговый контроль со стороны государства за производством спирта и его продажей стал осуществляться в форме патентного сбора - налога на право производства или торговли алкоголем и акциза - налога на алкоголь как предмет потребления (Мухамедина, 2009: 84).

Несмотря на то, что Положение о питейном сборе 1861 г. регламентировало функционирование винно-водочного производства, объектами акцизного обложения являлся и ряд других продуктов потребления, в том числе акциз с продажи сахара, введенный в стране в 1848 г., с нефтяного масла, используемого в освещении - в 1859 г., с табачных изделий - в 1865 г., с дрожжей - в 1866 г., с керосина - в 1872 г., со спичек - в 1888 г.

Акцизная реформа сопровождалась формированием специализированных органов - акцизных управлений на окружном и губернском уровне. В 1896 г. в составе Министерства финансов было создано Главное управление неокладных сборов и казенной продажи питий, что позволило более эффективно осуществлять контроль за поступлением акцизных сборов. Следует также отметить поэтапный характер ввода в действие Положения о питейном сборе 1861 г. на территории Российской империи. Так, акцизная система взимания питейного налога начала вводиться в стране с 1 января 1863 г., в том числе в Сибири и Степном крае. В сентябре 1866 г. ее действие распространили на Царство Польское, в 1869 г. - на Туркестанское генерал-губернаторство, в 1873-1878 гг. на Закавказье. Последним регионом, где в 1887 г. была введена акцизная система питейного налога, стала Закаспийская область (Борщик, 2017).

В конце XIX в. правящие круги Российской империи пришли к пониманию необходимости введения государственной монополии на продажу алкогольной продукции. Причиной данной ситуации стала необходимость борьбы с частным монополизмом в данной отрасли. Кроме этого, правительство рассчитывало, что «введение государственной винной монополии увеличит «доходы казны за счет извлечения торговой прибыли», сократит «масштабы пьянства» и создаст «более благоприятные условия для поместного землевладения и развития сельского хозяйства за счет поддержки сельскохозяйственного винокурения и гарантированного сбыта спирта в казну по выгодным ценам» (Артемьева, 2012: 113). Однако на территории Туркестана и ряда других этнорегионов государственная винная монополия не была введена.

\section{2. Материалы и методы}

В статье использовались нормативно-правовые акты, регламентирующие акцизную систему и деятельность специализированных налоговых органов - акцизных управлений в Российской империи: Положение о питейном сборе 1861 г., Положение о казенной продаже питей 1894 г., Устав об акцизных сборах (Нюренбург, 1912). История создания акцизной службы в центральноазиатских окраинах Российской империи реконструировалась на основе материалов делопроизводства региональных налоговых органов. Они представлены отчетами акцизных управлений, их перепиской с Министерством финансов. Ценным источником информации при подготовке статьи стали материалы сенаторской ревизии К.К. Палена Туркестанского генерал-губернаторства (1908 г.), отложившиеся в фонде 1396 РГИА (РГИА. Ф. 1396. Оп. 1. Д. 428). Материалы ревизии позволяют существенно дополнить историю формирования акцизных управлений в Туркестанском генералгубернаторстве, выявить проблемы в их деятельности, связать рост акцизных поступлений с развитием отдельных отраслей промышленности в регионе. При подготовке статьи также использовались статистические источники - ежегодные Обзоры областей Степного и Туркестанского генерал-губернаторств, которые формировали областные статистические управления; в них концентрировалась информация по целому спектру аспектов развития областей, в том числе налоговой системы. В Обзорах представлены суммарные данные по акцизным поступлениям, а также информация о количестве предприятий, занимающихся производством товаров, подлежавших патентному сбору, и продававших товары, облагавшиеся акцизом.

Методологической основой статьи выступила теория модернизации, в рамках которой формирование и развитие системы акцизного налогообложения в Степном и Туркестанском генералгубернаторствах рассматривается как один из аспектов региональной социально-экономической политики. Для реализации задач исследования применялся историко-генетический метод, позволивший реконструировать причины создания и генезис системы акцизных сборов в данном этнорегионе, выявить взаимосвязь акцизных сборов с развитием определенных отраслей производства. Историко-сравнительный метод использовался для выявления общих и специфических тенденций функционирования акцизной системы в Степном и Туркестанском генерал-губернаторствах, причин и факторов, обусловивших особенность протекания данного процесса в каждой из исследуемых административно-территориальных единиц. В рамках историкосистемного подхода история формирования и развития акцизной системы в центральноазиатских окраинах рассматривается как составная часть государственной экономической политики Российской империи 6о-х гг. XIX - начала XX вв. 


\section{3. Обсуждение}

История акцизной политики Российской империи достаточно детально представлена в историографии. Значительное количество работ по данной теме нацелено на сравнительный анализ акцизно-откупной системы и государственной винной монополии, выявления их позитивных тенденций и отрицательных последствий для экономики государства. Исследователи подчеркивают, что винокурение и виноторговля как основные источники поступления акцизных сборов в большинстве случаев «рассматривались не как элемент хозяйственно-экономической жизни страны, а как специфическое направление экономической деятельности, область особых (фискальных) интересов государства» (Бочанова, 1976; Шепелев, 1981; Мариупольский, 2000).

Отдельным направлением историографии акцизной реформы в Российской империи второй половины XIX - начала XX вв. следует считать ее региональный аспект (Копылов, 1973; Сметнева, 2006). На местном источниковедческом материале исследователи выявляют локальные особенности реализации реформы, ее последствия для социально-экономического развития регионов. В отношении Западной Сибири, к которой экономически тяготели области Степного генералгубернаторства, отмечается, что винокурение стало одним из наиболее развитых производств обрабатывающей промышленности региона, составлявших к концу XIX в. около 30 \% от общей суммы производства. По мнению ряда исследователей, это было связано с отсутствием спроса на внешних рынках на сибирский хлеб и, как следствие, его переизбыток на местных рынках (Андрющенко, 1980; Тужиков, 1964; Мариупольский, 2000). Следует также отметить, что в исследованиях сибиреведов, посвященных акцизно-откупной системе и государственной винной монополии, как правило, ситуация в степных областях не анализируется. Это объясняется «геоэкономическими, социально-экономическими и культурно-историческими различиями Акмолинской, Семипалатинской и Тургайской областей», нахождением их «на более низкой ступени развития» (Мариупольский, 2000: 24).

Среди авторов, так или иначе затрагивающих отдельные аспекты формирования налоговой системы центральноазиатских окраин, следует назвать Е.А. Правилову, Ю.А. Лысенко, А.С. Жанбосинову, Б.А. Алимджанова и др. (Правилова, 2006; Алимджанов, 2015; Лысенко, Жанбосинова, 2019; Lysenko, Chekryzhova, 2021). Исследователи отмечают, что формирование налоговой системы Степного края и Туркестана осуществлялось в рамках общеимперского законодательства, конечной задачей являлась ее унификация и приведение к общероссийским стандартам и нормам. В то же время на данный процесс значительное влияние оказывал ряд факторов, связанных с особенностями цивилизационного развития региона. Среди них - его трансграничность, приоритет геополитических интересов политики России в регионе, господство традиционных экономических отношений, слабая интегрированность региональной экономики в общероссийскую и, как следствие, незначительное присутствие в ней рыночного сектора и соответствующей ему инфраструктуры, замедленные темпы урбанизации и т.д.

Вместе с тем представляется, что распространение на центральноазиатские окраины России акцизной системы и государственной винной монополии выступало важным аспектом их интеграции в социально-экономическое пространство империи. Все это требует детального анализа ситуации, выявления локальных особенностей протекания данного процесса.

\section{4. Результаты}

Выше уже отмечалось, что Акмолинская и Семипалатинская области исторически и экономически тяготели к Западной Сибири. Этим объясняется тот факт, что в период проведения акцизной реформы 1861 г. они были включены в состав двух Акцизных управлений, административно входивших в состав Тобольской и Томской губерний - Тобольско-Акмолинского и ТомскоСемипалатинского. Таким образом, в Степном генерал-губернаторстве вплоть до конца имперского периода не появилось автономного Акцизного управления.

Поступление акцизных сборов обеспечивалось в Акмолинской и Семипалатинской областях, как и в целом по Западной Сибири, прежде всего благодаря развитию производства винокуренной отрасли, чему благоприятствовал ряд факторов. В первую очередь следует отметить, что акцизная реформа аннулировала практику передачи права торговли алкогольной продукцией на региональном рынке откупщикам. На основе Положения о питейном сборе 1861 г. была сформирована абсолютно новая система виноторговли, особенно розничной, основанная на рыночных механизмах. Как отмечают исследователи, частная инициатива обеспечила «резкий рост уровня технического и организационного обеспечения технологического процесса производства алкоголя. Возможность не облагать акцизом сверхнормативное производство спирта заставила заводчиков полностью переоборудовать винокуренные заводы. За несколько лет они не только догнали по уровню технической оснащенности западные заводы, но и во многом превзошли их» (Артемьева, 2011: 124). За двадцатилетний период проведения реформы, с 1861 по 1881 гг., численность частных винокуренных заводов в Западной Сибири (с учетом Акмолинской и Семипалатинской областей) увеличилось в 14 раз, их общая производительность выросла почти вдвое, а казенное производство спирта исчезло полностью (Мариупольский, 2014: 207). 
Развитие винокуренной промышленности было связано с массовым крестьянским переселением в Степной край в 70-80 е гг. XIX в. и ростом аграрного производства. В эти годы правительством была сформирована специальная структура - Переселенческое управление - и был принят ряд законодательных актов, что позволило упорядочить переселенческое движение, организовать его централизованные потоки и места расселения крестьян. Тургайская, Акмолинская и Семипалатинская области стали регионами активного выхода мигрантов. За период 1871-1896 гг. в Степной край переселилось 327,8 тыс. человек (Бекмаханова, 1996). Удельный вес коренного казахского населения сократился с 73,4 \% от общей численности населения в 70-е гг. XIX в. до 67,7 в 1897 г. Численность славянского населения возросла с 8,2 \% до 22,8 соответственно. Крестьянская колонизация Степного края кардинально изменила структуру аграрного производства региона: здесь активно стало развиваться земледелие, быстрыми темпами увеличивались посевные площади, ориентированные на выращивание злаковых культур. Однако в ситуации отсутствия развитой транспортной системы увеличивавшиеся урожаи хлеба не находили спроса на внешних рынках. Его переизбыток на региональном рынке нашел применение в развитии производства спирто-водочной продукции.

Важным моментом в развитии рынка спиртных напитков в Степном крае являлась его исключительная ориентация на местного потребителя - крестьянство. Это отразилось и на формировавшейся структуре виноторговли. Основным типом торгового заведения по реализации крепких спиртных напитков в Степном крае являлись питейные дома и пивные лавки. К концу ХIX в. крупнейшим производителем алкогольной продукции в Семипалатинской области стал Торговый

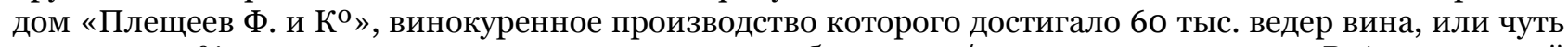
меньше 50 \% регионального производства, 150 рабочих - 1/3 занятых в отрасли. В Акмолинской области, как и в соседних Тобольской и Томской губерниях, одним из крупнейших заводчиков был А.Ф. Поклевский-Козелл (Шайдуров, 2013: 92).

Обзоры областей Степного края позволяют выявить количество предприятий по производству алкогольной продукции и, соответственно, размеры патентных и акцизных поступлений от ее реализации. Например, в 1895 г., к моменту принятия Положения о казенной продаже питей 1894 г., под контролем Семипалатинского акцизного округа находились: 1 винокуренный завод, 1 водочный завод, 3 пивоваренных завода, 3 медоваренных завода, 6 оптовых складов вина, 1 оптовый склад русских виноградных вин, 23 ренсковских погреба, 5 погребов русских виноградных вин, 11 трактирных заведений, 3 буфета, 3 временных выставки, 46 пивных лавок, 85 питейных домов. Кроме этого, акцизный и патентный сборы в области поступали от 1 спичечной фабрики, 273 табачных лавок с продажей продукции, 93 табачных лавок, работавших на продажу продукции и листов табака, 3 лавок - на развоз табака. Итого, Семипалатинским акцизным округом контролировалась работа 561 предприятия. По сравнению с предыдущим, 1894 г., число заведений, контролируемых чиновниками акцизного ведомства, возросло на 173, а сумма патентного сбора увеличилась на 4938 руб. Всего по области в 1895 г. патентного сбора поступило 24689,73 руб., акцизных поступлений от продажи водочной продукции, пива, меда и табака - 501 615,87 руб. (Обзор Семипалатинской..., 1897: 60-61).

Несколько иная ситуация складывалась в Туркестанском генерал-губернаторстве. В отличие от Степного края, к началу проведения акцизной реформы регион был слабо интегрирован в экономическое пространство Российской империи. Кроме этого, здесь крайне медленными темпами формировалось восточнославянское крестьянское население: области Туркестана фактически до начала XX в. были официально закрыты для переселения. Поэтому развитие местного винокуренного и спиртоводочного производства - основной статьи акцизных сборов - здесь не могло активно развиваться по объективным причинам - отсутствию спроса.

Распространение акцизной системы в традиционных обществах Туркестана также было в первое время крайне проблематичным. Известны попытки правителей Кокандского ханства до его завоевания Российской империей введения налогов на отдельные виды продаваемых товаров - соли и угля. Но они взимались непосредственно на базаре, по факту купли-продажи товара. Поэтому с юридической точки зрения их вряд ли можно было бы относить к косвенным налогам. Обложение производства крепких напитков также было невозможно из-за малого количества его употребления коренными народами Туркестана и соответственно малых объемов производства. Поэтому с введением Временного положения об управлении Туркестанским генерал-губернаторством в 1867 г. надзор за акцизными сборами был возложен на чиновников областных правлений, которые непосредственно починялись военным губернаторам областей (РГИА. Ф. 1396. Оп. 1. Д. 428. Л. 1190б.).

Система акцизных сборов в Туркестанском крае стала принимать общероссийские стандарты в 80-90-е гг. ХІХ в., когда здесь появились отдельные отрасли промышленного производства. Кроме этого, в регионе в данный период произошел рост предприятий винокуренной промышленности, что было связано с формированием потребительного рынка в лице российских воинских подразделений Туркестанского военного округа и Семиреченского казачьего войска. В соответствии с действовавшими правилами солдаты и офицеры должны были получать винную порцию в определенные дни (9 общепринятых праздников) и по медицинским показаниям. В условиях 
отсутствия транспортных коммуникаций производство алкогольной продукции выгоднее было организовать на месте.

Развитие винокуренной отрасли в крае и рост акцизных сборов актуализировали вопрос о создании Туркестанского акцизного управления. Оно было сформировано в Туркестанском генералгубернаторстве в 1886 г. в составе управляющего, ревизора, секретаря и его помощника, 10 участковых надзирателей, 13 надсмотрщиков (РГИА. Ф. 1396. Оп. 1. Д. 428. Л. 120). С 1888 г. в район действия Туркестанского акцизного управления была передана Семиреченская область, с 1900 г. - Закаспийская область, за исключением Мангышлакского уезда, причисленного к Астраханскому акцизному управлению. В 1906 г. в поле деятельности Управления вошли русские поселения Бухарского эмирата.

К 1910 гг. Туркестанское акцизное управление делилось на три окружных управления: в ведомство 1-го - с центром в г. Ташкенте входили Сырдарьинская (кроме Амударьинского отдела) и Ферганская области, Ходжентский уезд Самаркандской области; во 2-е (г. Самарканд) - входили остальные уезды Самаркандской области, Амударьинский отдел и русское поселение Бухарского эмирата; в состав 3-го (г. Верный) - была причислена Семиреченская область. Закаспийская область в территориальной структуре Туркестанского акцизного управления являлась автономной и управлялась акцизным наблюдателем, который располагался в г. Асхабаде. Численность штата Туркестанского акцизного управления составляла 79 человек (РГИА. Ф. 1396. Оп. 1. Д. 428. Л. 146об.).

Производство и продажа алкогольной продукции в Туркестане находилась в частных руках, в большей степени бухарских евреев. Уже с 1868 г. была введена практика выдачи патентов как «туземным», так и «русским» евреям на выкурку вина. В 1870-е гг. они были фактически уравнены в правах с прочим коренным населением Туркестана. В 1874 г. перед Туркестанской казенной палатой был поставлен вопрос о предоставлении евреям возможности заниматься питейной торговлей в крае. Межправительственная дискуссия по данному вопросу завершилась принятием закона 1888 г. «О правах евреев на винокурение и торговлю крепкими напитками в Туркестанском крае», на основании которого разрешалось «производство винокурения и торговли крепкими напитками лишь тем евреям в Туркестанском крае, которые принадлежат к туземному населению, и притом только в пределах Сырдарьинской, Самаркандской и Ферганской областей». Торговля вином могла производиться только из домов и торговых заведений, владельцами которых были иудеи. Однако, несмотря на то, что бухарским евреям были предоставлены возможности развития винокуренного производства, «к концу XIX в. их присутствие в отрасли было практически свернуто. Об этом свидетельствуют данные ведомственной статистики и переписи 1897 г. Так, в Самаркандской области лишь один еврей самостоятельно занимался производством спиртных напитков» (Bochkareva, Tarasova, 2019).

Следует сказать о и протекционистской политике, которую проводило государство в отношении отдельных групп предпринимателей, занимающихся развитием винокуренной промышленности в Туркестане. Речь идет прежде всего о французском предпринимателе Готье, имевшем в г. Каракуле Бухарского эмирата сеть виноградоводочных и винодельных заводов. На основании особого распоряжения Министерства финансов от 1905 г. ему было разрешено производить «виноградное вино без контрольного снаряда, с учетом спирта по нормам и действительным выходам, и употреблять ежедневную выкурку на сдабривание виноградных вин по мере надобности». Также ему была предоставлена возможность производить сдабривание вин с добавлением безакцизного спирта и доведением их крепости до 21 градуса вместо 12, как это было установлено для остальных туркестанских виноделов (РГИА. Ф. 1396. Оп. 1. Д. 428. Л. 121).

Ревизующая Туркестан сенаторская комиссия К.П. Палена в 1908 г. отмечала, что ситуация с винно-водочными предприятиями Готье не отвечала экономическим интересам Российской империи. Так, при создании компании предполагалось, что она будет осуществлять торговлю производимыми винами только в пределах Бухарского эмирата, без права ввоза собственно на территорию Российской империи. Однако к началу XX в. в результате проводившейся политики интеграции Бухарского эмирата таможенная граница между ним и Россией фактически была аннулирована. Объемы производства продукции предприятий Готье, благодаря предоставленным льготам, неизменно росли, и запрещенный ввоз на территорию империи нарушался. В страну под видом ввоза материалов для купажа и выделки других, более изящных вин - сладких и ликерных на самом деле ввозили крепленные до 21 градуса вина предприятий Готье. В России они находили наибольший спрос, чем менее крепкие, 12-градусные, вина других российских виноделов. Кроме этого, льготы Готье наносили сильный удар государственной казне. По подсчетам комиссии К.П. Палена они могли составить до 94500 руб. в год. В своем заключении комиссия К.П. Палена рекомендовала Управлению неокладных сборов и казенной продажи питей Министерства финансов рассмотреть возможность лишения винно-водочных предприятий Готье всех налоговых преференций (РГИА. Ф. 1396. ОП. 1. Д. 428. Л. 1210б.). 
В 1897 г. в правительственных кругах было принято решение о переходе от акцизно-откупной системы к государственной винной монополии ${ }^{1}$. Новая реформа предполагала поэтапное введение в действие новой системы производства и продажи спиртных напитков, что было связано со стремлением предоставить предпринимательским кругам высвобождение капиталов из данной отрасли производства. В результате территория империи была разделена на 8 очередей. С 1901 г. государственная винная монополия была введена в европейской части России. Западная Сибирь Тобольская и Томская губернии, а вместе с ними Акмолинская и Семипалатинская области вошли в 8 очередь - действие государственной винной монополии распространилось на регион в 1904 г. (Колокольников, 1914: 4). С введением государственной винной монополии частная винокуренная промышленность в областях Степного края прекратила существование. Концентрация в руках государства права винной торговли привела к резкому сокращению патентных сборов. Акцизные сборы от казенной продажи винно-водочной продукции продолжали расти по некоторым областям Степного края.

Вопрос о введении в Туркестане государственной монополии на производство и продажу водочной продукции возник в начале XX в. Соответствующее ходатайство возбудило Главное управление неокладных сборов Министерства финансов. Однако Туркестанское акцизное управление считало, что существующий порядок винной торговли «вполне отвечает современному положению вещей». Переход от него к казенной продаже питей оно считало преждевременным, так как «подобная реформа, в частности оборудование казенных винных складов, была бы сопряжена, ввиду местных условий, со слишком большими расходами для казны» (РГИА. Ф. 1396. ОП. 1. Д. 428. Л. 148об.).

Поэтому с начала XX в. и до 1917 г. в Туркестане продолжала функционировать акцизная система. Благодаря ее сохранению в регионе продолжало развиваться свободное производство спирта, торговля алкогольной продукцией ничем не ограничивалась. За этот период площади, занятые под выращивание винограда, неизменно увеличивались. Так, если в Сырдарьинской области в 1895 г. они составляли 340 десятин, то в 1910 г. - 2310 десятин. Около 40 \% выращенного винограда шло на изготовление вина. Из-за более раннего его созревания, по сравнению с другими районами России и Западной Европы, вина Туркестана были очень популярны за пределами региона. Винокуренная промышленность работала в основном на внешний рынок. Этому факту благоприятствовало развитие транспортных коммуникаций и строительство ОренбургскоТашкентской железной дороги. Винно-водочное производство обеспечивало неизменный прирост акцизных сборов в Сырдарьинской области, который иногда составлял до 10,4 \% в год. При этом акциз с продажи вина и спирта этой области в 1910 г. увеличился, по сравнению с предыдущим годом, на 20,2 \%, с пива - 13,3 \% (Обзор Сыр-Дарьинской..., 1912: 95, 127).

Несколько иная ситуация складывалась в табачном производстве. Акцизные сборы с этого товара в Туркестане, напротив, сокращались, иногда, по сравнению с предшествующими годами, в три раза. Ситуация объяснялась низким качеством туркестанского табака, который не выдерживал конкуренции с табачными изделиями, поставляемыми из европейской России (Обзор СырДарьинской..., 1912: 128). Помимо винокуренной и табачной промышленности, акцизы взимались с продажи пива, дрожжей, сахара, нефтепродуктов и спичек. В целом, размеры акцизных поступлений и патентного сбора в Туркестане за период с 1906 по 1908 гг., представленные в материалах сенаторской ревизии К.П. Палена, отражены в таблице 1 (РГИА. Ф. 1396. Оп. 1. Д. 428. Л. 1480б.).

Таблица 1. Размеры акцизных сборов Туркестана в 1906-1908 гг. (в рублях)².

\begin{tabular}{|c|c|c|c|c|c|c|c|c|c|}
\hline \multirow{2}{*}{$\begin{array}{l}\text { Наименов } \\
\text { ание } \\
\text { дохода }\end{array}$} & \multicolumn{3}{|c|}{ Сырдарьинская область } & \multicolumn{3}{|c|}{ Ферганская область } & \multicolumn{3}{|c|}{ Самаркандская область } \\
\hline & 1906 г. & $1907 \Gamma$. & 1908 г. & 1906 г. & $1907 \Gamma$. & 1908 г. & 1906 г. & 1907 г. & 1908 г. \\
\hline $\begin{array}{l}\text { Акцизы: } \\
\text { с } \\
\text { хлебного } \\
\text { вина и } \\
\text { спирта }\end{array}$ & $\begin{array}{l}\hat{\kappa} \\
\hat{a} \\
0 \\
\text { a }\end{array}$ & 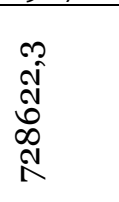 & $\begin{array}{l}\text { 2 } \\
\infty \\
0 \\
\hat{0} \\
\stackrel{N}{N}\end{array}$ & 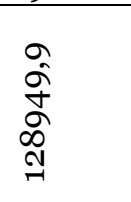 & 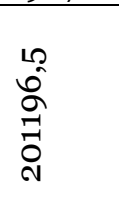 & $\begin{array}{l}\text { N } \\
\text { ๙̃ } \\
\text { Oे } \\
\text { î } \\
\text { î }\end{array}$ & 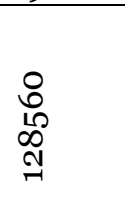 & $\begin{array}{l}0 \\
0 \\
0 \\
0 \\
0 \\
0\end{array}$ & 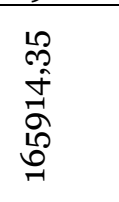 \\
\hline
\end{tabular}

1 Государственную винную монополию в историографии принято рассматривать в двух проекциях: с одной стороны - это фискальная сторона монополии, вид косвенного обложения государством, с другой - огромное предприятие государства, в котором винокурение предоставляется частным предпринимателям, но развитие производства на них и постройка новых заводов ставились в зависимость от Министерства финансов. Цены на продажу спиртной продукции также устанавливались государством.

2 Знак «?» в таблице обозначает неразборчивость количественных показателей в документе 
Bylye Gody. 2021. 16(4)

\begin{tabular}{|c|c|c|c|c|c|c|c|c|c|}
\hline $\begin{array}{l}\text { с } \\
\text { коньячно } \\
\text { го и } \\
\text { виноград } \\
\text { ного } \\
\text { спирта }\end{array}$ & ' & ' & ' & ' & ' & ' & a. & $\begin{array}{l}\stackrel{\text { L }}{+} \\
\text { ஸ̂ं } \\
\text { जे } \\
\text { ஸे }\end{array}$ & 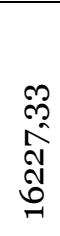 \\
\hline $\begin{array}{l}\text { дополни- } \\
\text { тельно с } \\
\text { водочных } \\
\text { изделий }\end{array}$ & 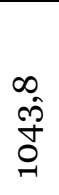 & 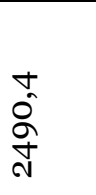 & $\begin{array}{l}2 \\
0 \\
0\end{array}$ & ' & 1 & 1 & I & 1 & ' \\
\hline пива & $\begin{array}{l}10 \\
\infty \\
0 \\
\circ \\
\text { Nू }\end{array}$ & $\begin{array}{l}\text { જे } \\
\text { ळे }\end{array}$ & $\begin{array}{l}n \\
0 \\
0 \\
\delta \\
\infty\end{array}$ & 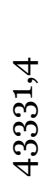 & $\begin{array}{l}0 \\
0 \\
0 \\
0 \\
0 \\
o\end{array}$ & \begin{tabular}{l}
0 \\
$\infty$ \\
$\hat{N}$ \\
$\hat{N}$ \\
\multirow{\gamma}{*}{}
\end{tabular} & $\begin{array}{l}0 \\
\infty \\
\infty \\
\end{array}$ & $\begin{array}{l}\text { 志 } \\
\infty \\
\infty \\
0\end{array}$ & $\begin{array}{l}15 \\
\infty \\
0 \\
0\end{array}$ \\
\hline дрожжей & $\stackrel{\text { N }}{\mathrm{N}}$ & مُ & ' & ' & ' & ' & ' & $\stackrel{\leftrightarrow}{q}$ & $\begin{array}{l}\stackrel{2}{~} \\
\stackrel{f}{\gamma}\end{array}$ \\
\hline табака & 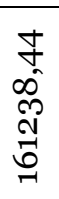 & 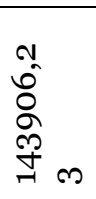 & 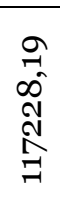 & $\begin{array}{l}12 \\
10 \\
\text { مी } \\
\text { N }\end{array}$ & $\begin{array}{l}0 \\
0 \\
0 \\
\text { Oे } \\
\text { ? }\end{array}$ & $\begin{array}{l}N \\
\infty \\
N \\
N \\
N\end{array}$ & 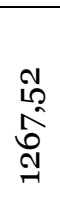 & 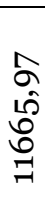 & 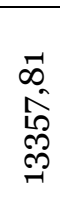 \\
\hline сахара & \begin{tabular}{l} 
Na \\
\multirow{2}{+}{} \\
Nิ \\
\end{tabular} & ' & $\begin{array}{l}\text { הి } \\
\text { în }\end{array}$ & ' & ' & ' & ' & ' & ' \\
\hline $\begin{array}{l}\text { нефтяных } \\
\text { продуктов }\end{array}$ & $\begin{array}{l}\text { No } \\
\text { N } \\
\text { Iิ } \\
\infty\end{array}$ & I & ' & $\begin{array}{l}\infty \\
10 \\
10 \\
\stackrel{0}{10}\end{array}$ & 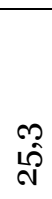 & $\begin{array}{l}\infty \\
10 \\
\vec{n} \\
-1 \\
\end{array}$ & స్ & ' & ' \\
\hline спичек & 1 & $\begin{array}{l}0 \\
\text { O) } \\
\text { O্ }\end{array}$ & $\begin{array}{l}\forall \\
\text { ஸ̂ } \\
\text { î }\end{array}$ & ' & , & 1 & ' & ' & ' \\
\hline $\begin{array}{l}\text { Патентно } \\
\text { го сбора: } \\
\text { С заводов } \\
\text { и } \\
\text { производс } \\
\text { тв по по } \\
\text { выделке } \\
\text { питей }\end{array}$ & $\begin{array}{l}0 \\
0 \\
0 \\
10 \\
10\end{array}$ & 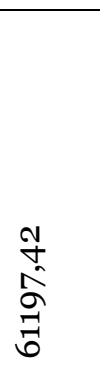 & 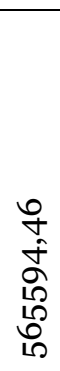 & 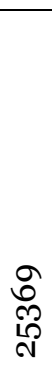 & 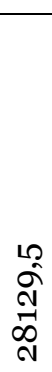 & \begin{tabular}{l} 
J \\
10 \\
\multirow{2}{*}{} \\
10 \\
0 \\
0
\end{tabular} & n. & $\begin{array}{l}12 \\
0 \\
\infty \\
8 \\
2 \\
2\end{array}$ & $\begin{array}{l}10 \\
\hat{N} \\
\infty \\
0 \\
\hat{N}\end{array}$ \\
\hline $\begin{array}{l}\text { Фабрик и } \\
\text { заведений } \\
\text { производ- } \\
\text { ства и и } \\
\text { продажи } \\
\text { табака }\end{array}$ & $\begin{array}{l}\text { \& } \\
\text { ఫे } \\
\text { N }\end{array}$ & 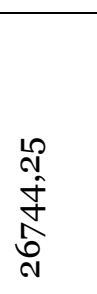 & $\begin{array}{l}\text { م } \\
\text { ô } \\
\text { స̃ } \\
\text { ปे }\end{array}$ & $\begin{array}{l}12 \\
\hat{\alpha} \\
\hat{+} \\
\hat{N}\end{array}$ & $\begin{array}{l}10 \\
1 \\
\infty \\
\text { Nิ } \\
\infty \\
\infty \\
-1\end{array}$ & $\begin{array}{l}\infty \\
0 \\
10 \\
\infty \\
\infty \\
\infty \\
\infty \\
1\end{array}$ & $\begin{array}{l}10 \\
0 \\
0 \\
0 \\
\infty\end{array}$ & 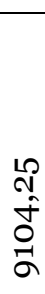 & $\begin{array}{l}10 \\
\stackrel{1}{\infty} \\
\infty \\
\tilde{N} \\
\infty\end{array}$ \\
\hline $\begin{array}{l}\text { Сахарных } \\
\text { и } \\
\text { рафинад- } \\
\text { ных } \\
\text { заводов }\end{array}$ & $\begin{array}{l}\infty \\
\infty \\
\hat{~} \\
\infty \\
\infty\end{array}$ & $\begin{array}{l}\infty \\
0 \\
\infty \\
\curvearrowleft \\
\sigma\end{array}$ & \begin{tabular}{l}
$\stackrel{\infty}{N}$ \\
\multirow{J}{*}{} \\
$\infty$
\end{tabular} & 1 & ' & ' & ' & ' & 1 \\
\hline
\end{tabular}




\begin{tabular}{|c|c|c|c|c|c|c|c|c|c|}
\hline $\begin{array}{l}\text { Спичеч- } \\
\text { ных } \\
\text { фабрик }\end{array}$ & ' & I & 占 & 1 & 1 & I & 1 & 1 & 1 \\
\hline итого & 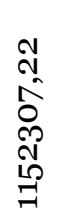 & 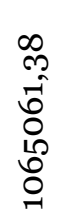 & \begin{tabular}{l}
$\infty$ \\
m \\
-1 \\
-1 \\
\multirow{+}{*}{} \\
0 \\
0
\end{tabular} & 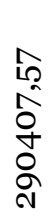 & 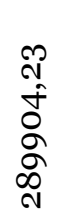 & 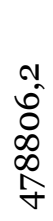 & ค. & $\begin{array}{l}\infty \\
\infty \\
\infty \\
\infty \\
\infty \\
\infty \\
\stackrel{N}{0}\end{array}$ & 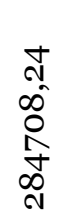 \\
\hline
\end{tabular}

На основании статистических данных, отраженных в Обзорах областей Степного и Туркестанского генерал-губернаторств, составлен Рисунок 1, отражающий динамику поступления акцизного сбора за отдельные годы.

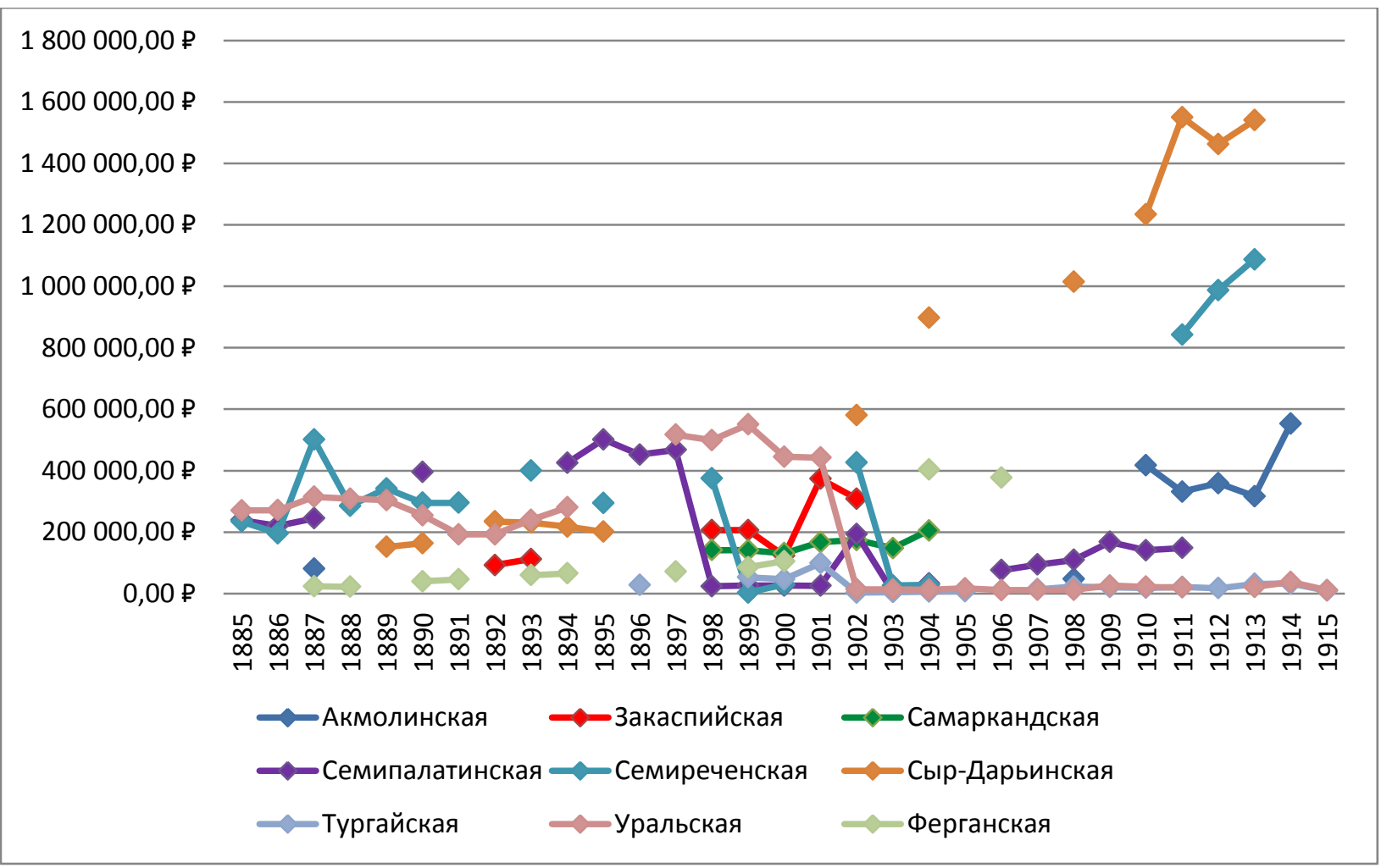

Рис. 1. Объемы акцизных и патентных сборов в областях Степного и Туркестанского генерал-губернаторств в 1885-1915 гг. (в руб.)

По данным Рисунка 1 следует, что размеры акцизных сборов в центральноазиатском регионе Российской империи были подвержены значительным колебаниям. В Степном крае в период развития частного предпринимательства в винокуренной отрасли отмечалась достаточно ровная ситуация, связанная с поступлением акцизных и патентных сборов. Они не превышали по отдельным областям 600 тыс. руб. в год. После введения государственной винной монополии в 1902 г. размеры акцизных и патентных сборов в областях Степного края сократились.

В Сырдарьинской, Самаркандской областях Туркестанского генерал-губернаторства в начале $\mathrm{XX}$ в. в связи с сохранением винокуренной промышленности в частном секторе экономики, увеличением площадей виноградных плантаций и строительством железнодорожных коммуникаций произошло увеличение акцизных и патентных сборов с производства и продажи винно-водочной продукции.

Низкие патентные и акцизные сборы с других видов производства и продукции в центральноазиатских окраинах Российской империи можно объяснить начальным этапом формирования отдельных отраслей промышленности и незначительными объемами производства, а также низкой покупательской способностью населения региона. По данным Б.А. Алимджанова, акцизные сборы в Туркестанском крае в расчете на одну душу населения составили в 1896 г. менее 0,14 руб., тогда как по России данные сборы в том же году составили на одну душу населения 3,16 руб. 
(Алимджанов, 2015: 27-33). В целом, косвенные налоги, собираемые в Степном крае и Туркестане, так и не стали приносить государственной казне существенных доходов.

\section{5. Заключение}

Целью акцизной реформы в Степном крае и Туркестане выступила интеграция данного этнорегиона в российскую экономику, повышение его рентабельности. В Степном крае увеличение акцизных поступлений в государственную казну во второй половине XIX в. было связано с развитием прежде всего винокуренной промышленности. Этому благоприятствовал ряд факторов: разрешение свободного производства спирта, ничем не ограниченной торговли алкогольными напитками, развитие сырьевой базы данной отрасли и рост спроса на продукцию, благодаря резкому притоку в регион крестьянского населения. После введения в начале XX в. государственной винной монополии размеры акцизных сборов по областям Степного края стали сокращаться. В Туркестане введение в действие положений акцизной реформы началось позднее - в 70-80 е гг. XIX в. Это было связано с более поздним подключением региона к модернизационным процессам, отсутствием в нем спроса на винно-водочную продукцию, ориентацией правительственных кругов на развитие хлопководческих хозяйств. Тем не менее к концу XIX в. в результате развития железнодорожной сети винокуренная промышленность в Туркестане, сориентированная на российский рынок, стал приносить значительные налоговые поступления. Государственная винная монополия начала XX в. не затронула регион.

\section{6. Благодарности}

Подготовка статьи осуществлена при финансовой поддержке Совета по грантам Президента Российской Федерации в рамках проекта НШ-2693.2020.6 «Государственное регулирование социальных процессов в центральноазиатском регионе России имперского и советского периодов».

\section{Литература}

Алимджанов, 2016 - Алимджанов Б.А. Налоговая политика Российской империи в Туркестанском генерал-губернаторстве // Вестник Московского городского педагогического университета. 2015. № 3 (19). С. 27-33.

Андрющенко, 1980 - Андрющенко Б.К. Обрабатывающая промышленность Сибири второй половины XIX в. // Промышленность и рабочие Сибири в период капитализма. Новосибирск, 1980. C. $35-56$.

Артемьева, 2011 - Артемьева Л.В. Этапы и механизмы введения в России акцизной системы на алкоголь во второй половине XIX в. // Транспортное дело России. 2011. № 5. С. 122-125.

Артемьева, 2012 - Артемъева Л.В. Причины и механизмы введения винной монополии в России в конце XIX в. // Транспортное дело России. 2012. С. 114-118.

Бекмаханова, 1996 - Бекмаханова Н.Е. Многонациональное население Казахстана и Северной Киргизии в эпоху колониализма. М., 1996. 279 с.

Борщик, 2017 - Борщик Н.Д. К истории акцизных управлений Российской империи второй половины XIX - начала XX в. // Ученые записки Крымского федерального университета имени В.И. Вернадского. Серия «Исторические науки». 2017. Том 3 (69). № 3. С. 79-90.

Бочанова, 1976 - Бочанова Г.А. Винокуренная промышленность и казенная винная монополия в Западной Сибири. Конец XIX - начало XX в. // Некоторые вопросы истории древней и современной Сибири. Новосибирск, 1976. С. 60-69.

Кравцова, 2010 - Кравцова E.C. Опыт организации налогового дела в России в конце XIX начале XX столетия. Курск, 2010. 303 с.

Колокольников, 1914 - Колокольников К.А. Развитие винной монополии в Томской губернии с Семипалатинской областью, в связи с историей винной монополии в Сибири. Томск, 1914. 233 с.

Копылов, 1973 - Копылов Д.И. Обрабатывающая промышленность Западной Сибири в XVIII первой половине XIX вв. Свердловск, 1973. 501 с.

Лысенко, Жанбосинова, 2019 - Лысенко Ю.А., Жанбосинова А.С. Система государственного налогообложения городского недвижимого имущества в центральноазиатских окраинах Российской империи (конец XIX - начало XX в.) // Известия Алтайского госуниверситета. 2019. № 5 (109). C. $49-54$.

Мариупольский, 2000 - Мариупольский А.М. Винокурение и виноторговля Западной Сибири в период действия акцизной системы (1863-1902 гг.). Барнаул, 2000. 158 с.

Мариупольский, 2014 - Мариупольский А.М. Некоторые аспекты формирования рынка спиртных напитков Сибири в период действия акцизной системы во второй половине XIX в. // Известия Алтайского госуниверситета. 2014. № 4 (56). С. 206-211.

Мухамедина, 2009 - Мухамедина ШІ. Акцизы и винная монополия в Российской империи // Финансы и кредит. 2009. № 37 (373). С. 81-88.

Нюренбург, 1912 - Нюренбург А.М. Уставы об акцизных сборах. М., 1912. 1140 с. 
1897. $93 \mathrm{c}$.

Обзор Семипалатинской..., 1897 - Обзор Семипалатинской области за 1895 год. Семипалатинск,

Обзор Сыр-Дарьинской..., 1912 - Обзор Сыр-Дарьинской области за 1910 г. Ташкент, 1912. 233 с.

Положение о питейном сборе..., 1862 - Положение о питейном сборе, высочайше утвержденное 4 июля 1861 года, с присовокуплением высочайше утвержденного 20 марта 1862 года правил о взысканиях за нарушение постановлений о питейном сборе и судопроизводстве по сим делам. M., $1862.160 \mathrm{c.}$

Правилова, 2006 - Правилова E.A. Финансы империи. Деньги и власть в политике России на национальных окраинах, 1801-1917. М., 2006. 453 с.

РГИА - Российский государственный исторический архив.

Сметнева, 2006 - Сметнева Н.В. Развитие винокурения и виноторговли в Прибайкалье во второй половине XVII - начале XX в. Иркутск, 2006. 238 с.

Тужиков, 1964 - Тужиков В.И. О формировании пролетариата Сибири во второй половине XIX в. (1861-1891 гг.) // Вопросы истории Сибири. Вып. 1. Томск, 1964. С. 56-65.

Шайдуров, 2013 - Шайдуров В.Н. О некоторых особенностях формирования и экономического развития польской общины Западной Сибири XIX - начала XX в. // Вестник археологии, антропологии и этнографии. 2013. № 4. С. 88-97.

Шепелев, 1981 - Шепелев Л.Е. Царизм и буржуазия во второй половине XIX в. Л., 1981. 275 с.

Bochkareva, Tarasova, 2019 - Bochkareva I.B., Tarasova E.V. Bukhara Jews and Distillation in Turkestan in the late 1860s-1890s // Bylye Gody. 2019. 52(2): 677-685.

Lysenko, Chekryzhova, 2021 - Lysenko Yu.A., Chekryzhova O.I. Formation of System of Fishing Fees from Industry and Trade in the Central Asian Outskirts of the Russian Empire // Bylye Gody. 2021. 16(3): $1277-1287$.

\section{References}

Alimdzhanov, 2015 - Alimdzhanov, B.A. (2015). Nalogovaya politika Rossijskoj imperii v Turkestanskom general-gubernatorstve. [Tax policy of the Russian Empire in the Turkestan General Government]. Vestnik Moskovskogo gorodskogo pedagogicheskogo universiteta. 3(19): 27-33. [in Russian]

Andryushchenko, 1980 - Andryushchenko, B.K. (1980). Obrabatyvayushchaya promyshlennost' Sibiri vtoroj poloviny XIX v. [The processing industry of Siberia in the second half of the 19th century]. Promyshlennost' i rabochie Sibiri v period kapitalizma. Novosibirsk, pp. 35-56. [in Russian]

Artemeva, 2011 - Artemeva, L.V. (2011). Etapy i mekhanizmy vvedeniia v Rossii aktsiznoi sistemy na alkogol vo vtoroi polovine XIX v. Transportnoe delo Rossii. [Stages and mechanisms of the introduction of the excise system for alcohol in Russia in the second half of the 19th century]. Transportnoe delo Rossii. 5: 122-125. [in Russian]

Artem'eva, 2012 - Artem'eva, L.V. (2012). Prichiny i mekhanizmy vvedeniya vinnoj monopolii v Rossii $\mathrm{v}$ konce XIX v. [The reasons and mechanisms for the introduction of the wine monopoly in Russia at the end of the 19th century]. Transportnoe delo Rossii. 5: 114-118. [in Russian]

Bekmahanova, 1996 - Bekmahanova, N.E. (1996). Mnogonacional'noe naselenie Kazahstana i Severnoj Kirgizii $\mathrm{v}$ epohu kolonializma. [The multinational population of Kazakhstan and northern Kyrgyzstan in the era of colonialism]. M., 279 p. [in Russian]

Bochanova, 1976 - Bochanova, G.A. (1976). Vinokurennaya promyshlennost' i kazennaya vinnaya monopoliya v Zapadnoj Sibiri. Konec XIX - nachalo XX v. [The distillery industry and the state-owned wine monopoly in Western Siberia. Late 19th - early 20th century]. Nekotorye voprosy istorii drevnej i sovremennoj Sibiri. Novosibirsk, pp. 6o-69. [in Russian]

Bochkareva, Tarasova, 2019 - Bochkareva, I.B., Tarasova, E.V. (2019). Bukhara Jews and Distillation in Turkestan in the late 1860s-189os. Bylye Gody. 52(2): 677-685.

Borshchik, 2017 - Borshchik, N.D. (2017). K istorii akciznyh upravlenij Rossijskoj imperii vtoroj poloviny XIX - nachala XX v. [On the history of excise administrations of the Russian Empire in the second half of the XIX - early XX century]. Uchenye zapiski Krymskogo federal'nogo universiteta imeni V.I. Vernadskogo. Seriya «Istoricheskie nauki». Tom 3 (69). 3: 79-90. [in Russian]

Kolokol'nikov, 1914 - Kolokol'nikov, K.A. (1914). Razvitie vinnoj monopolii v Tomskoj gubernii s Semipalatinskoj oblast'yu, v svyazi s istoriej vinnoj monopolii v Sibiri. [The development of a wine monopoly in the Tomsk province with the Semipalatinsk region, in connection with the history of the wine monopoly in Siberia]. Tomsk, 233 p. [in Russian]

Kopylov, 1973 - Kopylov, D.I. (1973). Obrabatyvayushchaya promyshlennost' Zapadnoj Sibiri v XVIII - pervoj polovine XIX vv. [Manufacturing industry of Western Siberia in the 18th - first half of the 19th centuries]. Sverdlovsk, 501 p. [in Russian]

Kravcova, 2010 - Kravcova, E.S. (2010). Opyt organizacii nalogovogo dela v Rossii v konce XIX nachale XX stoletiya. [The experience of organizing the tax business in Russia at the end of the 19th the beginning of the 2oth century]. Kursk, 303 p. [in Russian] 
Lysenko, Chekryzhova, 2021 - Lysenko, Yu.A., Chekryzhova, O.I. (2021). Formation of System of Fishing Fees from Industry and Trade in the Central Asian Outskirts of the Russian Empire. Bylye Gody. 16(3): 1277-1287.

Lysenko, Zhanbosinova, 2019 - Lysenko, Yu.A., Zhanbosinova, A.S. (2019). Sistema gosudarstvennogo nalogooblozheniya gorodskogo nedvizhimogo imushchestva $\mathrm{v}$ central'noaziatskih okrainah Rossijskoj imperii (konec XIX - nachalo XX v.). [The system of state taxation of urban real estate in the Central Asian outskirts of the Russian Empire (late 19th - early 2oth centuries)]. Izvestiya Altajskogo gosuniversiteta. 5(109): 49-54. [in Russian]

Mariupol'skij, 2000 - Mariupol'skij, A.M. (2000). Vinokurenie i vinotorgovlya Zapadnoj Sibiri v period dejstviya akciznoj sistemy (1863-1902 gg.). [Distilling and wine trade in Western Siberia during the period of the excise system (1863-1902)]. Barnaul, 158 p. [in Russian]

Mariupol'skij, 2014 - Mariupol'skij, A.M. (2014). Nekotorye aspekty formirovaniya rynka spirtnyh napitkov Sibiri v period dejstviya akciznoj sistemy vo vtoroj polovine XIX v. [Some aspects of the formation of the alcoholic beverages market in Siberia during the period of the excise system in the second half of the 19th century]. Izvestiya Altajskogo gosuniversiteta. 4(56): 206-211. [in Russian]

Muhamedina, 2009 - Muhamedina, Sh. (2009). Akcizy i vinnaya monopoliya v Rossijskoj imperii. [Excise taxes and wine monopoly in the Russian Empire]. Finansy i kredit. 37(373): 81-88. [in Russian]

Nyurenburg, 1912 - Nyurenburg, A.M. (1912). Ustavy ob akciznyh sborah [Charters on excise duties]. M., 1140 p. [in Russian]

Obzor Semipalatinskoj..., 1897 - Obzor Semipalatinskoj oblasti za 1895 god. Semipalatinsk, 93 p. [in Russian]

Obzor Semipalatinskoj..., 1912 - Obzor Semipalatinskoj oblasti za 1910 god. Tashkent, 233 p. [in Russian]

Polozhenie o pitejnom sbore..., 1862 - Polozhenie o pitejnom sbore, vysochajshe utverzhdennoe 4 iyulya 1861 goda, s prisovokupleniem vysochajshe utverzhdennogo 20 marta 1862 goda pravil o vzyskaniyah za narushenie postanovlenij o pitejnom sbore i sudoproizvodstve po sim delam [Regulation on drinking collection, the highest approved on July 4, 1861, with the addition of the highest approved on March 20, 1862, the rules on penalties for violation of orders on drinking collection and legal proceedings in these cases]. M., $160 \mathrm{p}$.

Pravilova, 2006 - Pravilova, E.A. (2006). Finansy imperii: den'gi i vlast' v politike Rossii na nac. okrainah, 1801-1917. [Finance of the Empire: money and power in Russian politics at the national level suburbs, 1801-1917]. Moscow, 453 p. [in Russian]

RGIA - Rossijskij gosudarstvennyj istoricheskij arhiv [Russian State Historical Archives].

Shajdurov, 2013 - Shajdurov, V.N. (2013). O nekotoryh osobennostyah formirovaniya i ekonomicheskogo razvitiya pol'skoj obshchiny Zapadnoj Sibiri XIX - nachala XX v. [On some features of the formation and economic development of the Polish community of Western Siberia in the XIX - early XX century]. Vestnik arheologii, antropologii i etnografii. 4: 88-97. [in Russian]

Shepelev, 1981 - Shepelev, L.E. (1981). Tsarizm i burzhuaziya vo vtoroj polovine XIX v. [Tsarism and the bourgeoisie in the second half of the 19th century]. Leningrad, 275 p. [in Russian]

Smetneva, 2006 - Smetneva, N.V. (2006). Razvitie vinokureniya i vinotorgovli v Pribajkal'e vo vtoroj polovine XVII - nachale XX v. [The development of distilling and wine trade in the Baikal region in the second half of the 17th - early 2oth century]. Irkutsk, 238 p. [in Russian]

Tuzhikov, 1964 - Tuzhikov, V.I. (1964). O formirovanii proletariata Sibiri vo vtoroj polovine XIX v. (1861-1891 gg.). [On the formation of the proletariat of Siberia in the second half of the XIX century. (18611891)]. Voprosy istorii Sibiri. Vyp. 1. Tomsk, pp. 56-65. [in Russian]

\section{Формирование системы акцизных сборов в центральноазиатских окраинах Российской империи (вторая половина XIX - начало XX вв.)}

Юлия Александровна Лысенко a, , c, *

а Алтайский государственный университет, Барнаул, Российская Федерация

в Черкас глобальный университет, Вашингтон, США

с Волгоградский государственный университет, Волгоград, Российская Федерация

Аннотация. В статье на основе разноплановых по происхождению исторических источников, впервые введенных в научный оборот, анализируется процесс создания на центральноазиатских окраинах Российской империи системы акцизных сборов. Отмечается, что целью акцизной реформы в Степном крае и Туркестане являлась модернизация и интеграция в российскую экономику данного

${ }^{*}$ Корреспондирующий автор
Адреса электронной почты: iulia_199674@mail.ru (Ю.А. Лысенко) 
этнорегиона, повышение его рентабельности. В Степном крае увеличение акцизных поступлений в государственную казну во второй половине XIX в. было связано с развитием прежде всего винокуренной промышленности. Этому благоприятствовал ряд факторов: разрешение свободного производства спирта, ничем не ограниченной торговли алкогольными напитками, развитие сырьевой базы данной отрасли и рост спроса на продукцию, благодаря резкому притоку в регион крестьянского населения. После введения в начале XX в. государственной винной монополии размеры акцизных сборов по областям Степном края стали сокращаться. В Туркестане введение в действие положений акцизной реформы началось позднее - в 70-80 е гг. XIX в. Это было связано с более поздним подключением региона к модернизационным процессам, отсутствием в нем спроса на винноводочную продукцию, ориентацией правительственных кругов на развитие хлопководческих хозяйств. Тем не менее к концу XIX в. в результате развития железнодорожной сети винокуренная промышленность в Туркестане, сориентированная на российский рынок, стала приносить значительные налоговые поступления. Государственная винная монополия начала XX в. не затронула регион.

Ключевые слова: акцизная реформа, винокуренная промышленность, государственная винная монополия, Российская империя, Степной край, Туркестан. 